\title{
Agricultural Chemicals in Iowa's \\ Ground Water, 1982-95- What Are the Trends?
}

The Iowa Department of Natural Resources. Geological Survey Bureau: the University of Iowa Hygienic Laboratory; and the U.S. Geological Survey (USGS) have been working together to address this question. As part of the Iowa Ground-Water Monitoring Program (IGWM), water samples have been collected from selected Iowa municipal wells since 1982. An examination of this data identified two trends: (1) concentrations of atrazine in Iowa's ground water generally were decreasing over time, and (2) concentrations of metolachlor generally were increasing. Continuing ground-water sampling can determine if these trends represent long-term changes in chemical concentrations.

\section{BACKGROUND}

Iowa has some of the most productive farmland in the world. Agricultural chemicals (pesticides and nitrogen fertilizers) have become an integral part of farming in Iowa, where some of the most intensive applications in the United States are used (Battaglin and Goolsby, 1995). Intensive chemical use has focused investigations on Iowa to determine the occurrence of agricultural chemicals in ground water (Libra and others, 1987; Detroy and others, 1988; Hallberg, 1989; Kross and others, 1990). Research has documented that alachlor, atrazine, cyanazine, and metolachlor historically have been the most frequently detected pesticides in Iowa's ground water. This research has increased public awareness of the occurrence of agricultural chemicals in ground water. A public concern has been whether concentrations of agricultural chemicals have changed over time. Few studies, however, have provided the consistency and longevity to adequately address this issue on a regional scale (Barbash and Resek, 1996). In response to this concern, the Geological Survey Bureau, the University of Iowa Hygienic Laboratory, and the USGS formed the IGWM in 1982 to monitor agricultural chemicals in Iowa's ground water. From 1982-95, 2,041 nitrate samples from 1,024 municipal wells and 1,375 pesticide samples from 730 municipal wells were collected for the IGWM (fig. 1).

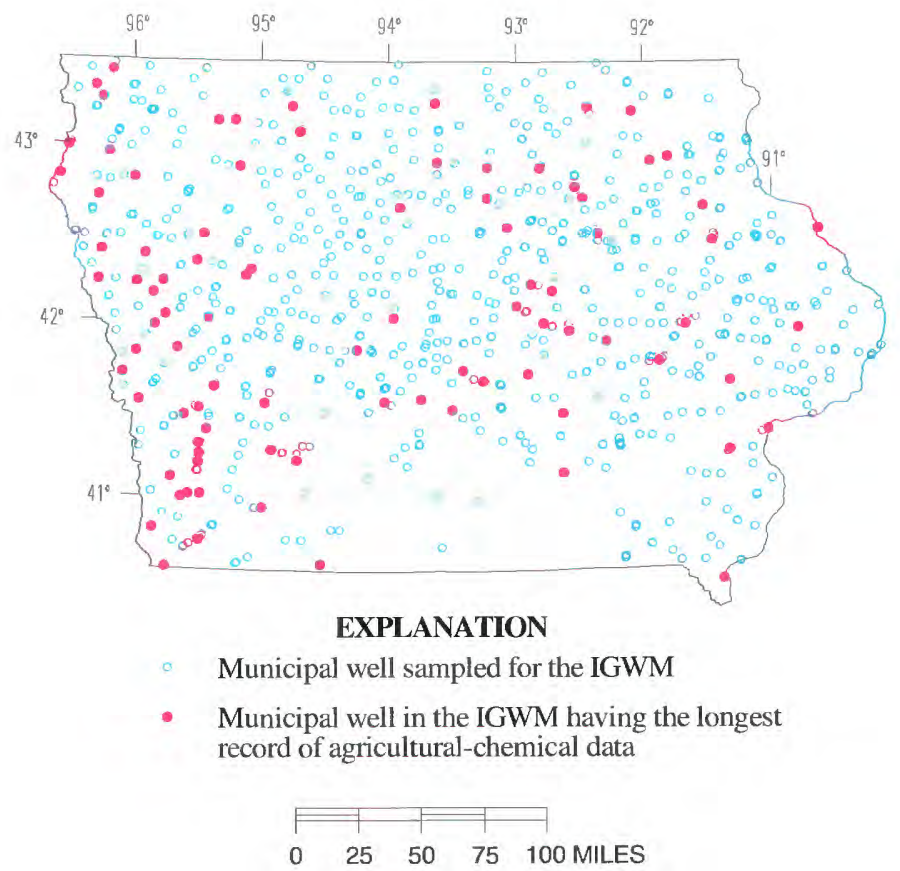

Figure 1. Location of the municipal wells sampled repeatedly from 1982-95 for the lowa Ground-Water Monitoring Program (IGWM).

\section{CHANGING CONCENTRATIONS}

Laboratory measurements of nitrate, alachlor, atrazine, cyanazine, and metolachlor were examined to determine if concentrations of agricultural chemicals have changed over time. These compounds were selected because they tend to be the most commonly detected agricultural chemicals in Iowa's ground water (Detroy and others, 1988; Hallberg, 1989). Samples collected over time from the same set of wells are the best samples to use to evaluate whether chemical concentrations in ground water are changing.
From 1982-95, 89 of the municipal wells in the IGWM were sampled repeatedly (fig. 1). An examination of the data from these 89 wells indicated no significant change between the 1982-86 and 198791 time periods for any of the chemicals examined. No significant changes were found in nitrate, alachlor, or cyanazine between the 1987-91 and 1992-95 time periods. Concentrations of these compounds increased or decreased in roughly equal numbers of wells (fig. 2). However, atrazine concentrations generally decreased through the later time periods, and metolachlor concentrations generally increased (fig. 2). 


\section{WHAT MIGHT BE CAUSING THE CHANGES?}

Two factors that could cause changes in the concentrations of agricultural chemicals in ground water are changes in precipitation (recharge) and in the amounts of chemicals applied to the land. Although precipitation is important, there are no obvious relations between precipitation and the temporal patterns found in this study for atrazine and metolachlor. However, statewide changes in chemical use and application rates (table 1) suggest a link to the temporal trends of decreasing atrazine and increasing metolachlor concentrations in ground water. The more frequently and intensively a chemical is used, the more likely that it might reach ground water. Statewide atrazine use decreased an estimated 12 percent, along with an estimated 40 percent decrease in intensity of use (mass per unit area), whereas statewide metolachlor use increased an estimated 50 percent (table 1 ).

\section{WHERE ARE THESE CHANGES OCCURRING?}

\section{Shallow Wells}

Changing concentrations of atrazine and metolachlor in ground water were most likely to be observed in shallow wells (fig. 3). This relation between tem-

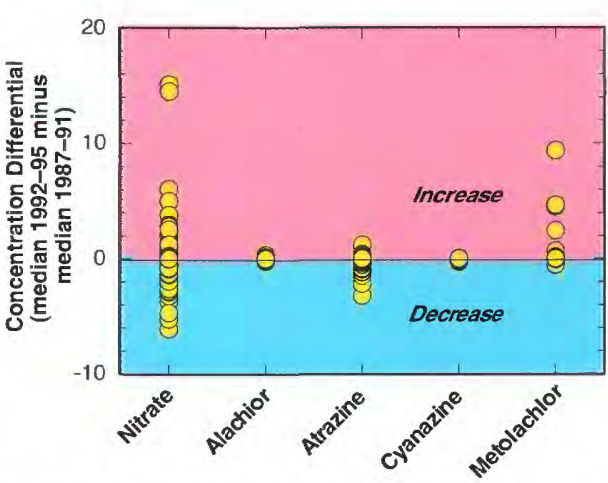

Figure 2. Concentration differential for selected agricultural chemicals. This concentration differential was calculated by subtracting the median 1987-91 concentration from the median 1992-95 concentration for the 89 wells having the longest record of agricultural-chemical data. The nitrate data are reported in parts per million, and the pesticide data are in parts per billion.

poral variability and well depth occurs because, as the distance between the land surface and the open interval of the well decreases, the ground water generally is younger (fig. 4). Consequently, changes in chemical applications at the land surface are indicated most rapidly in the youngest ground water.

\section{Alluvial Aquifers}

The changing concentrations of atrazine (decreasing) and metolachlor (increasing) were most apparent in alluvial aquifers (fig. 5). Alluvial aquifers are sand and/or gravel water-bearing deposits beneath flood plains along stream valleys (figs. 6, 7). Chemical changes were

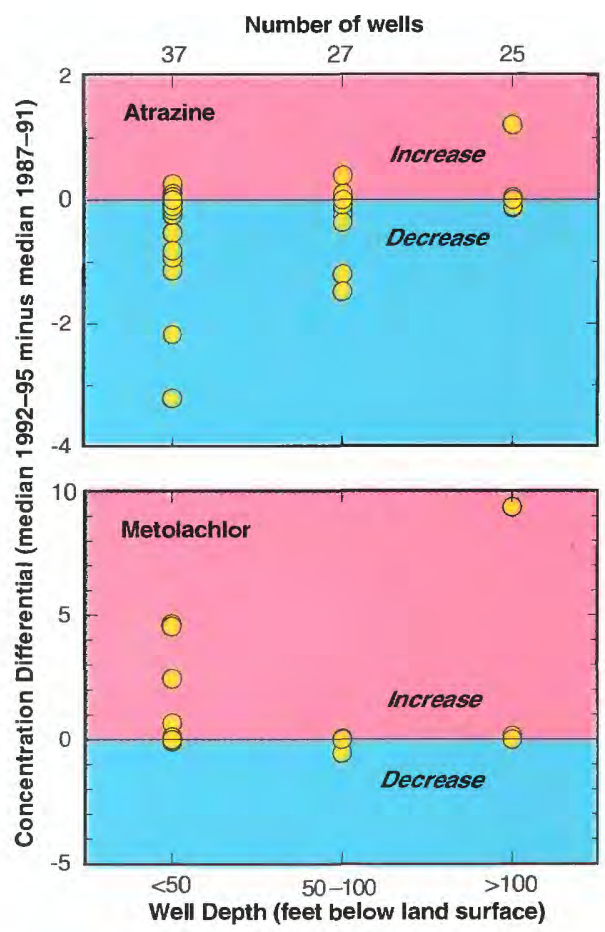

Figure 3. Concentration differential for selected agricultural chemicals by well depth. This concentration differential was calculated by subtracting the median 1987-91 concentration from the median 1992-95 concentration for the 89 wells having the longest record of agricultural-chemical data.

observed most frequently in alluvial aquifers because water from these aquifers tends to be younger than that from other aquifer types. Research by others also has shown alluvial aquifers to be more susceptible to contamination by agricultural chemicals than most other types of aquifers (Hallberg, 1989; Kolpin and others, 1994; Kolpin and others, 1997).

Table 1. Estimated use of selected agricultural chemicals in lowa, 1982-95

\begin{tabular}{|c|c|c|c|c|c|c|}
\hline \multirow[t]{2}{*}{ Compound } & \multicolumn{3}{|c|}{$\begin{array}{l}\text { Average chemical use } \\
\text { ( } 1,000 \text { pounds/year of } \\
\text { active ingredient })\end{array}$} & \multicolumn{3}{|c|}{$\begin{array}{l}\text { Average intensity of use } \\
\text { (pounds/acre) }\end{array}$} \\
\hline & $1982-86$ & $1987-91$ & 1992-95 & $1982-86$ & $1987-91$ & $1992-95$ \\
\hline $\begin{array}{l}\text { Nitrogen } \\
\text { fertilizer }^{1}\end{array}$ & $1,931.824$ & 1.844 .520 & 1.839 .168 & 138 & 129 & 118 \\
\hline Alachlor $^{2}$ & 13,800 & 8.246 & 5.180 & 2.01 & 2.25 & 2.28 \\
\hline Atrazine $^{2}$ & 8,179 & 7,451 & 7,195 & 1.46 & 0.96 & 0.90 \\
\hline Cyanazine $^{2}$ & 9.440 & 5.852 & 6,988 & 2.06 & 2.06 . & 2.32 \\
\hline Metolachlor $^{2}$ & 6,744 & 10,910 & 10,378 & 2.40 & 2.05 & 2.09 \\
\hline
\end{tabular}

${ }^{1}$ Vroomen, 1989; U.S. Department of Agriculture, 1995.

${ }^{2}$ Hartzler and Wintersteen, 1991; U.S. Department of Agriculture, 1995; Hallberg and others, 1996.

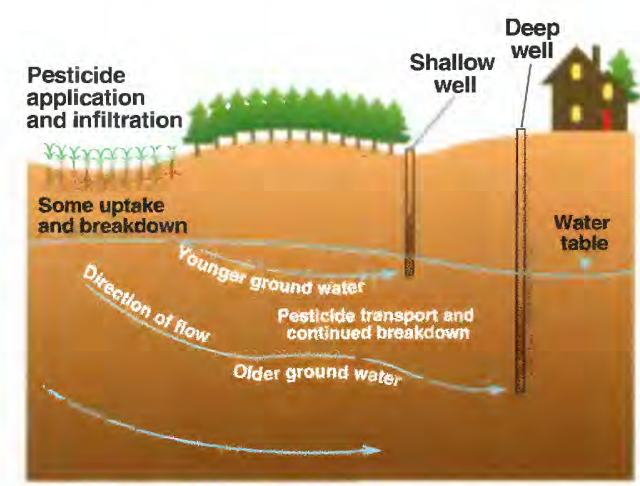

Figure 4. Generalized ground-water movement and pesticide transport in the subsurface (modified from Roberts and Jones, 1996). 


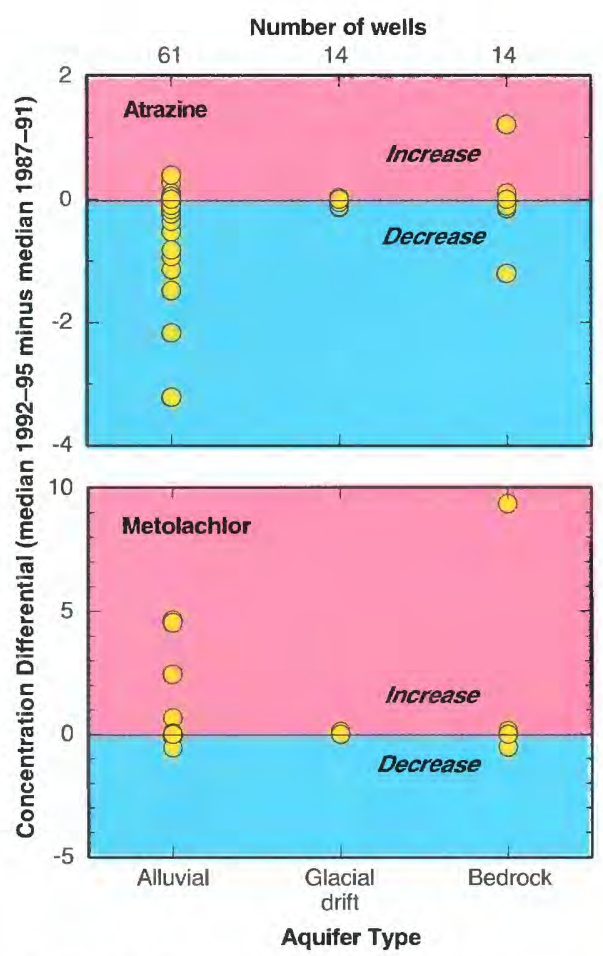

Figure 5. Concentration differential for selected agricultural chemicals by aquifer type. This concentration differential was calculated by subtracting the median 1987-91 concentration from the median 1992-95 concentration for the 89 wells having the longest record of agricultural-chemical data.

\section{MORE DATA NEEDED}

Identifying changes in agricultural-chemical concentrations in ground water is a primary benefit of a long-term program such as the IGWM. It is important, however, that data continue to be collected for the IGWM for several reasons. First, by collecting additional data, it can be determined if the changes in chemical concentrations reported in this study will continue over time. Because the variability in rainfall has been extreme in recent years-from the drought of the late 1980's to the record floods of 1993 - more time and data are needed to fully understand the impact of these climatic trends. Second, the types of chemicals being used in Iowa are continually changing as their marketing rises and falls (just think how the chemical advertisements you see have changed). Without adequate data, it cannot be determined how these changes in chemical use affect ground-water quality. Third, recent research (Potter and Carpenter, 1995; Kolpin and others, 1996, 1997) has shown that pesticides can degrade into other compounds (degradates) that commonly are being found in ground water throughout the United States. Without data on these degradates, an understanding of the environmental fate of agricultural chemicals will remain incomplete. Finally, more data may be needed to determine chemical changes in older ground water.

\section{ADDITIONAL READING}

The results presented in this fact sheet are summarized from a previously published research paper. Additional information on the results of this study is available in this paper:

Kolpin, D.W., Sneck-Fahrer, D.A., Hallberg, G.R., and Libra, R.D, 1996, Temporal trends of selected agricultural chemicals in Iowa's groundwater, 1982-95Are things getting better?: Journal of Environmental Quality, v. 26, no. 4, p. 1007-1017.

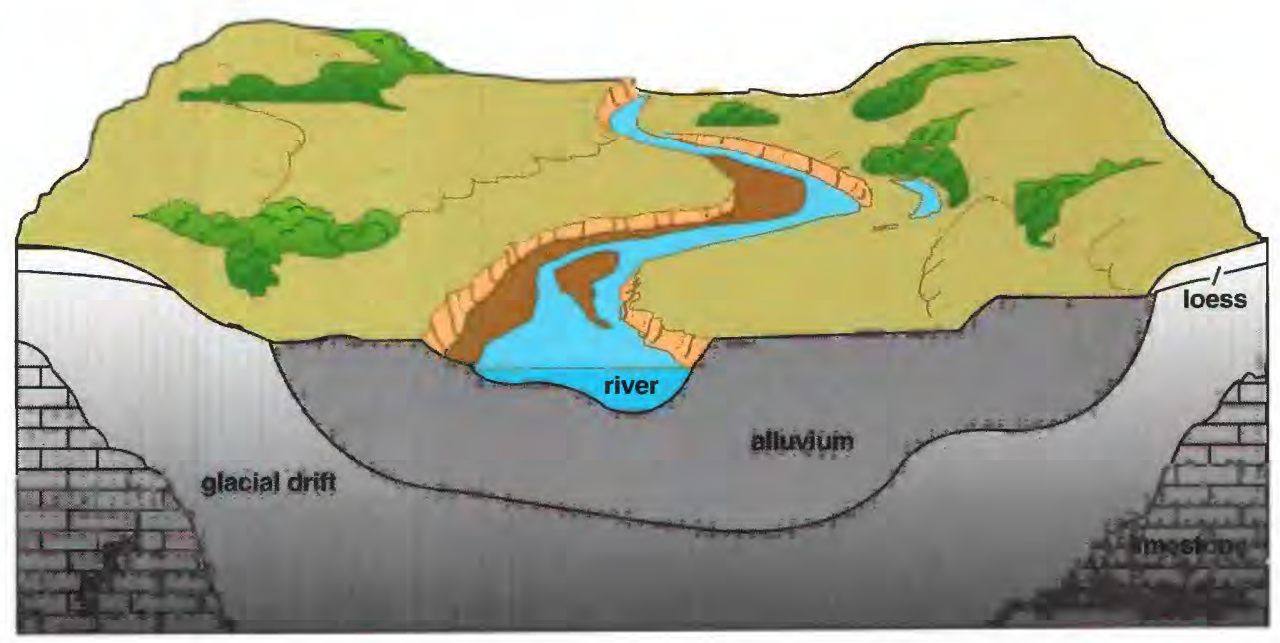

Figure 6. Conceptual geologic cross section of a typical alluvial aquifer in lowa (modified from Prior, 1991).

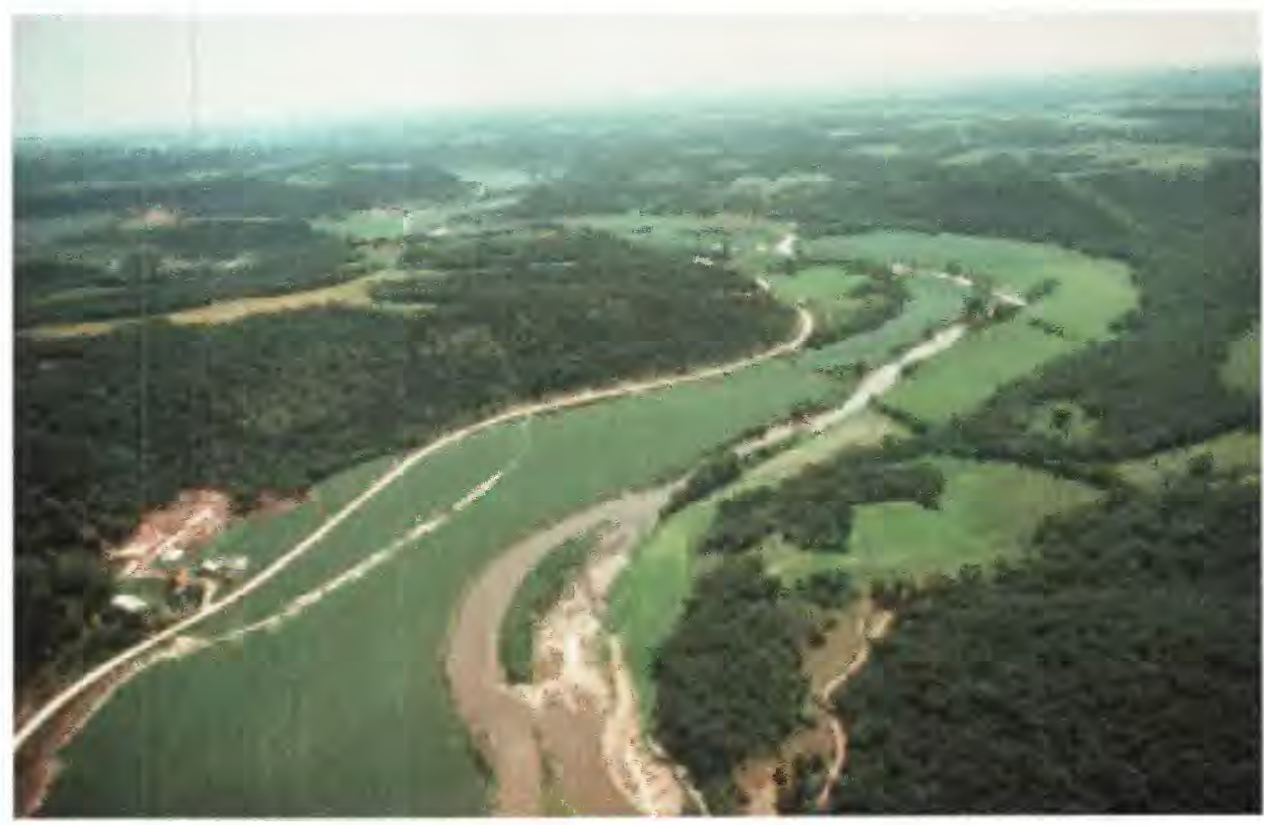

Figure 7. Aerial view of an alluvial aquifer in northeast lowa (Prior, 1991). 


\section{REFERENCES CITED}

Barbash, J.E., and Resek, E.A., 1996, Pesticides in ground water-Distribution, trends, and governing factors: Chelsea, Mich., Ann Arbor Press, Inc., 588 p.

Battaglin, W.A., and Goolsby, D.A., 1995, Spatial data in geographic information system format on agricultural chemical use, land use, and cropping practices in the United States: U.S. Geological Survey Water-Resources Investigations Report 94-4176, 87 p.

Detroy, M.G., Hunt, P.K., and Holub, M.A., 1988, Ground-water-quality-monitoring program in Iowa-Nitrate and pesticides in shallow aquifers: U.S. Geological Survey Water-Resources Investigations Report 88-4123, 31 p.

Hallberg, G.R., 1989, Pesticide pollution of groundwater in the humid United States: Agriculture Ecosystems \& Environment, v. 26, p. 299-367.

Hallberg, G.R., Riley, D.G., Kantamneni, J.R., Weyer, P.J., and Kelley, R.D., 1996, Assessment of Iowa Safe Drinking Water Act monitoring data1988-1995: The University of Iowa Hygienic Laboratory Research Report No. 97-1, 132 p.
Hartzler, R., and Wintersteen, W.K., 1991, A survey of pesticides used in Iowa crop production in 1990: Ames, Iowa State University Extension Service Publication Pamphlet 1441, 11 p.

Kolpin, D.W., Burkart, M.R., and Thurman, E.M., 1994, Herbicides and nitrate in near-surface aquifers in the midcontinental United States, 1991: U.S. Geological Survey Water-Supply Paper 2413,34 p.

Kolpin, D.W., Thurman, E.M., and Goolsby, D.A., 1996. Occurrence of selected pesticides and their metabolites in near-surface aquifers of the Midwestern United States: Environmental Science \& Technology, v. 30, p. 335-340.

Kolpin, D.W., Kalkhoff, S.J., Goolsby, D.A., Sneck-Fahrer, D.A., and Thurman, E.M., 1997, Occurrence of selected herbicides and herbicide degradation products in Iowa's ground water, 1995: Ground Water, v. 35, no. 4, p. 679-688.

Kross, B.C., and others, 1990, The Iowa State-wide rural well-water surveyWater-quality data, initial analysis: Iowa Geological Survey Technical Information Series Report 19, 142 p.
Libra, R.D., Hallberg, G.R., and Hoyer, B.E., 1987, Impacts of agricultural chemicals on groundwater in Iowa, in Fairchild, D.M., ed., Ground water quality and agricultural practices: Chelsea, Mich., Lewis Publisher, Inc., p. 185-217.

Potter, T.L., and Carpenter, T.L., 1995, Occurrence of alachlor environmental degradation products in groundwater: Environmental Science \& Technology, v. 29 , p. $1557-1563$.

Prior, J.C., 1991, Landforms of Iowa: Iowa City, University of Iowa Press, 153 p.

Roberts, L.M., and Jones, J.L., 1996, Pesticides found in ground water below orchards in the Quincy and Pasco Basins: U.S. Geological Survey Fact Sheet 171-96, $4 \mathrm{p}$.

U.S. Department of Agriculture, 1995, Agricultural chemical usage-1994 field crops summary: U.S. Department of Agriculture Report Ag CH 1 (95).

Vroomen, H., 1989, Fertilizer use and price statistics, 1960-1988: U.S. Department of Agriculture, Economic Research Service Statistics Bulletin $780,56 \mathrm{p}$.

- Dana Kolpin, George Hallberg, Debra Sneck-Fahrer, and Robert Libra

email: dwkolpin@usgs.gov

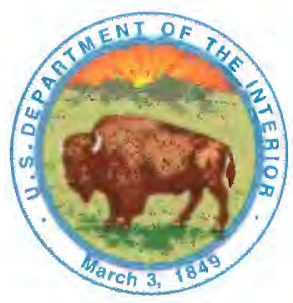

For more information please contact:

District Chief

400 S. Clinton Street

P.O. Box 1230

Iowa City, Iowa 52244

Telephone (319) 337-4194

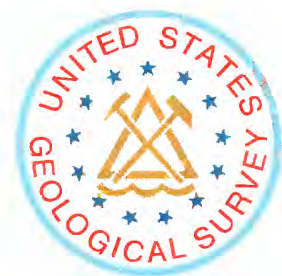

